ఠ

\title{
Marked leukocytosis in response to estramustine phosphate in a hormone-refractory prostate cancer patient
}

This article was published in the following Dove Press journal:

International Medical Case Reports Journal

15 April 2010

Number of times this article has been viewed

\author{
Tatsuo Morita \\ Department of Urology, Jichi \\ Medical University, Tochigi, Japan
}

Correspondence:Tatsuo Morita

Department of Urology, Jichi

Medical University, Shimotsuke-city,

Tochigi 3290498, Japan

Tel +8I 285406595

Fax +8I 285406595

Email moritatu@jichi.ac.jp
Abstract: A 67-year-old man was refered to our institution with a complaint of elevated serum prostate-specific antigen (PSA) level $(54 \mathrm{ng} / \mathrm{mL})$. Diagnosis was adenocarcinoma of the prostate with a Gleason score of 9, with bone metastasis (stageD2). He was treated with maximal androgen blockade followed by estramustine phosphate (EMP) because of the progression to hormone-refractory prostate cancer (HRPC). Leukocytosis over $20000 / \mu \mathrm{L}$ was repeatedly observed at each administration of EMP. This is the first case report of leukocytosis in response to EMP in an HRPC patient. The present case suggests that EMP could modulate leukocyte differentiation in HRPC patients.

Keywords: leukocytosis, neutrophilia, estramustine phosphate, hormone-refractory prostate cancer

\section{Introduction}

Estramustine phosphate (EMP), a carbamate ester of 17 beta-estradiol and nor-nitrogen mustard, has been used for the treatment of prostate cancer. Major toxicities by the treatment with EMP are gastrointestinal and cardiovascular events with less frequent leukopenia. ${ }^{1}$ On the other hand, an increase in white blood cell (WBC) counts by the treatment with EMP was reported by Daponte and colleagues in 1983 . $^{2}$ They examined changes in WBC counts in 12 hormone-naïve prostate cancer patients treated by EMP, and showed that WBC counts increased in response to the administration of EMP. However, in hormone-refractory prostate cancer (HRPC) patients, there have been no reports on leukocytosis in response to EMP. Herein, we present the first case report of leukocytosis which was repeatedly observed at each administration of EMP in an HRPC patient.

\section{Case report}

A 67-year-old man was refered to our institution with a complaint of elevated serum prostate-specific antigen (PSA) level (54 ng/mL) in 2004. A prostate biopsy revealed adenocarcinoma of the prostate with a Gleason score of $9(4+5)$. A systemic survey showed multiple bone metastasis. Based on the diagnosis of metastatic prostate cancer (stage D2), he received maximal androgen blockade (MAB) consisting of leuprorelin acetate and bicaldamide followed by flutamide. The other hospital medications were nifedipine, valsartan, trichlormethiazide, verapamil hydrochloride, aspirin, and subcutaneous insulin as he had hypertension, arrhythmia and diabetes mellitus. The PSA level decreased to the nadir of $0.7 \mathrm{ng} / \mathrm{mL}$ and then increased gradually 
up to $7 \mathrm{ng} / \mathrm{mL}$, which led to the diagnosis of hormonerefractory prostate cancer (HRPC) in 2006. He received EMP (313.4 mg/day) from December 2006 to July 2007. PSA level decreased and leukocytosis over $20000 / \mu \mathrm{L}$ occurred after the treatment with EMP (Figure 1). Serum C-reactive protein (CRP) levels, when leukocytosis was observed, were less than $0.35 \mathrm{mg} / \mathrm{dL}$. Systemic workups including physical examination, examinations of blood, urine and sputa, together with chest and abdominal CT, did not show any evidence of infection. Since EMP was considered as a potential cause of leukocytosis, we discontinued the administration of EMP in July 2007. Thereafter, the leukocyte count returned to the baseline level. The differential leukocyte count showed neutrophilia (over $7500 / \mu \mathrm{L}$ ) and monocytosis (over $500 / \mu \mathrm{L}$ ) although all the leukocyte subsets changed in number in response to EMP in more or less a similar fashion (Figure 2). Because of a PSA elevation due to the discontinuation of EMP, he received EMP again from December 2007 to July 2008. A similar change in leukocyte counts, due to the treatment with EMP, was observed again. Before July 2008, he had not received any steroids such as prednisolone and dexamethasone other than EMP. The PSA level decreased once by the EMP administration but thereafter increased gradually. Then, we switched EMP to the chemotherapy with docetaxel (DTX) in December 2008. ${ }^{3}$ Because of its adverse effect of fatigue, he chose the best supportive care and was transferred to a hospital near his home.

\section{Discussion}

Leukocytosis in solid tumor patients could be caused by various factors such as infections, bone marrow metastasis, and administration of corticosteroids. ${ }^{4,5}$ In the present case, it seems that leukocytosis was induced by EMP as leukocytosis was repeatedly observed after each administration of EMP without any sign of infection. A possible explanation for the leukocytosis observed might be as follows: EMP acts on normal cells involved in the hematopoiesis and/or prostate cancer cells themselves, ${ }^{6}$ and induces the production of hematopoiesis-associated colony-stimulating factors (CSFs), resulting in the leukocytosis. Furthermore, it was shown that estron and 17-beta-estradiol induce granulocytic differentiation in experimental studies. ${ }^{7,8}$ These studies support the possibility that major metabolites of EMP such as estron and 17-beta-estradiol might play an important role in the leukocytosis induced by EMP.

DTX-based chemotherapy is the standard therapy against HRPC based on the clinical trials of TAX 327. ${ }^{3}$ and SWOG 99-16. ${ }^{9}$ published in 2004. In the SWOG 99-16 study,

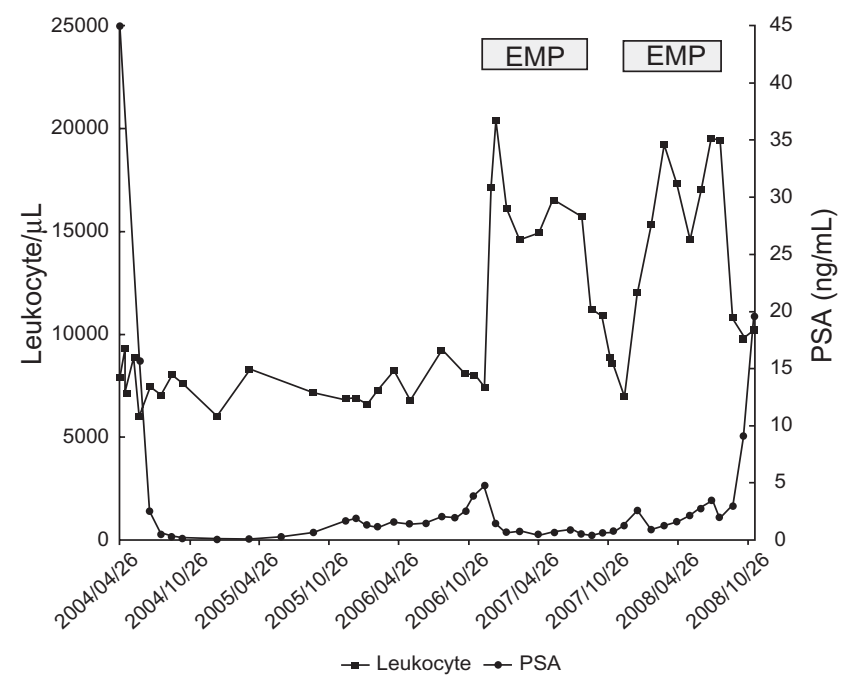

Figure I Changes in PSA level and leukocyte count during the hormone therapy. Abbreviation: PSA, prostate-specific antigen.

median survival time was longer in patients treated with DTX and EMP compared with those with mitoxantrone alone. ${ }^{9}$ However, whether EMP is necessary in combination with DTX is controversial. Considering leukopenia is the dose-limiting toxicity of DTX, the present finding of EMP-induced leukocytosis in an HRPC patient might imply an additional role of EMP in the chemotherapy with DTX against HRPC. Namely, EMP might have a myeloprotective effect in the chemotherapy with DTX as the third effect in addition to its cytotoxic and hormone effects. This implication is supported by the metaanalysis of patients with castration-refractory prostate cancer. ${ }^{10}$ This study showed that the addition of EMP to chemotherapy regimens decreases the risk of chemotherapy-related neutropenia compared with chemotherapy without EMP.

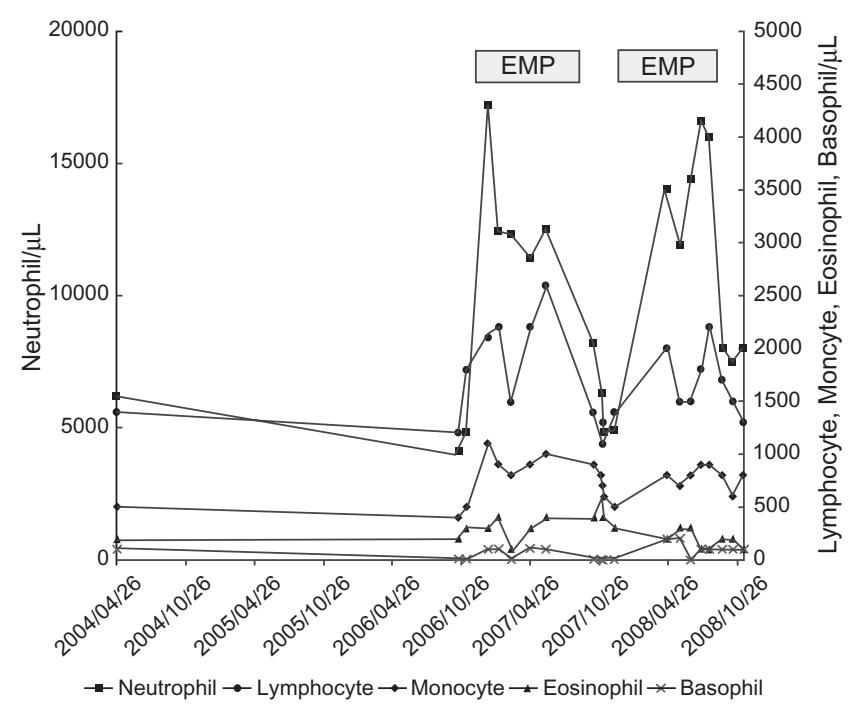

Figure 2 Changes in differential count of leukocytes during the hormone therapy. 
In conclusion, the present case suggests that EMP could modulate leukocyte differentiation in HRPC patients. However, further studies are required to examine the frequency and extent of leukocytosis in response to EMP in HRPC patients, to elucidate the mechanisms underlying the leukocytosis in response to EMP, and to clarify whether EMP has a myeloprotective effect in the DTX-based chemotherapy.

\section{Disclosure}

The author reports no conflicts of interest relevant to this work.

\section{References}

1. Van Poppel H, Baert L. The present role of estramustine phosphate in advanced prostate cancer. Prog Clin Biol Res. 1991;370:323-341.

2. Daponte D, Sylvester R, De Pauw M, et al. Change in white cell count during treatment of advanced cancer of the prostate with estramustine phosphate and with stilboestrol. Br J Urol. 1983;55:408-412.
3. Tannock IF, de Wit R, Berry WR, et al. Docetaxel plus prednisone or mitoxantrone plus prednisone for advanced prostate cancer. $N$ Engl $J$ Med. 2004;351(15):1502-1512.

4. Granger JM, Kontoyiannis DP. Etiology and outcome of extreme leukocytosis in 758 nonhematologic cancer patients: a retrospective, single-institution study. Cancer. 2009;115(17):3919-3923.

5. Kasuga I, Makino S, Kiyokawa H, Katoh H, Ebihara Y, Ohyashiki K. Tumor-related leukocytosis is linked with poor prognosis in patients with lung carcinoma. Cancer. 2001;92(9):2399-2405.

6. Savarese DM, Valinski H, Quesenberry P, et al. Expression and function of colony-stimulating factors and their receptors in human prostate carcinoma cell lines. Prostate. 1998;34:80-91.

7. Mountford JC, Bunce CM, Hughes SV, et al. Estrone potentiates myeloid cell differentiation: a role for 17 beta-hydroxysteroid dehydrogenase in modulating hemopoiesis. Exp Hematol. 1999;27(3):451-460.

8. Dietsch V, Kalf GF, Hazel BA. Induction of granulocytic differentiation in myeloblasts by 17-beta-estradiol involves the leukotriene D4 receptor. Recept Signal Transduct. 1996;6:63-75.

9. Petrylak DP, Tangen CM, Hussain MH, et al. Docetaxel and estramustine compared with mitoxantrone and prednisone for advanced refractory prostate cancer. N Engl J Med. 2004;351:1513-1520.

10. Fizazi K, Le Maitre A, Hudes G, et al. Addition of estramustine to chemotherapy and survival of patients with castration-refractory prostate cancer: a meta-analysis of individual patient data. Lancet Oncol. 2007;8:994-1000.
International Medical Case Reports Journal

\section{Publish your work in this journal}

The International Medical Case Reports Journal is an international, peer-reviewed open-access journal publishing original case reports from all medical specialties. Previously unpublished medical posters are also accepted relating to any area of clinical or preclinical science. Submissions should not normally exceed 2,000 words or

\section{Dovepress}

4 published pages including figures, diagrams and references. The manuscript management system is completely online and includes a very quick and fair peer-review system, which is all easy to use. Visit $\mathrm{http}: / / \mathrm{ww} w$. dovepress.com/testimonials.php to read real quotes from published authors.

Submit your manuscript here: http://www.dovepress.com/international-medical-case-reports-journal-journal 